\title{
IDENTIFIKASI FAKTOR PENENTU BESARAN INDEKS “K” DAN KEBIJAKAN PENETAPAN HARGA TBS KELAPA SAWIT POLA KEMITRAAN DI KABUPATEN MUARO JAMBI
}

\author{
A.Rahman ${ }^{1}$, Adlaida Malik ${ }^{2}$, Ratnawaty Siata \\ Program Magister Agribisnis Fakultas Pertanian Universitas Jambi \\ Email: adbur.jambee@yahoo.co.id \\ ida adlaidamalik@yahoo.com
}

\begin{abstract}
ABSTRAK
Penelitian ini bertujuan untuk mengidentifikasi faktor penentu besaran Indeks K dimana nilai Indeks $\mathrm{K}$ ini digunakan untuk penetapan harga Tandan Buah Segar kelapa sawit (TBS) yang dipedomi oleh perusahaan pabrik kelapa sawit dan petani. Analisis regresi dilakukan terhadap data historis bulanan dari tahun 2001 sampai 2012 yang bersumber dari data penetapan harga TBS di Dinas Perkebunan Provinsi Jambi. Dengan tingkat kesesuaian model $\left(\mathrm{R}^{2}\right)$ sebesar 41.9 , pengujian hipotesis pengaruh biaya pengolahan TBS menjadi Crude Palm Oil (CPO) dan minyak Inti Sawit (Palm Kernel Oil), biaya pemasaran, biaya penyusutan dan biaya operasional tidak langsung terhadap besaran indek $\mathrm{K}$ menunjukkan bahwa, harga biaya tidak langsung yang berpengaruh nyata terhadap besaran nilai Indeks $\mathrm{K}$, sementara variabel lainnya berpengaruh negatif tetapi tidak nyata dengan tingkat kepercayaan 10 persen. Kebijakan Pabrik Kelapa Sawit (PKS) dalam pembelian TBS menunjukkan bahwa PKS dengan Pola PIR Trans plus KKPA menetapkan harga di bawah harga ketetapan, sementara PKS pada pola PIR menetapkan harga di bawah harga ketetapan. Dari hasil penelitian juga ditemukan bahwa perusahaan yang mengelola kebun dengan pola KKPA menetapkan harga beli sesuai dengan ketetapan Tim Penetapan Harga TBS.
\end{abstract}

Kata Kunci: Indeks, Indeks K, Kebijakan Harga, TBS

\section{PENDAHULUAN}

Salah satu keunikan pasar tandan buah segar kelapa sawit (TBS) dibandingkan dengan komoditas pertanian lainnya di Indonesia adalah bahwa dalam penetapan harga TBS pemerintah melakukan pengendalian harga. Hal ini tercermin dari adanya Peraturan Menteri yang mengatur tentang mekanisme penetapan harga TBS, mulai dari Keputusan Menteri Kehutanan dan Perkebunan nomor 627 tahun 1998, direvisi menjadi Peraturan Menteri Pertanian (Pemertan) nomor 395 tahun 2005 hingga yang terakhir adalah Pemertan nomor 17 tahun 2010. Tujuan utama dari terbitnya Pemertan tersebut adalah memberikan perlindungan dalam perolehan harga wajar dari TBS kelapa sawit produksi petani dan menghindari adanya persaingan tidak sehat diantara pabrik kelapa sawit (PKS). 
Sesuai dengan ketentuan Pemertan nomor 17 tahun 2010 Pemerintah Daerah dalam hal ini Gubernur membentuk Tim Penetapan Harga TBS di Tingkat Provinsi yang beranggotakan wakil petani (Asosiasi Petani), unsur instansi pemerintah daerah, pelaku industri kelapa sawit dan perguruan tinggi. Salah satu tugas Tim tersebut sebagaimana tercantum dalam pasal 8 ayat 2 Pemertan nomor 17 tahun 2010 adalah merumuskan dan mengusulkan besarnta indeks " $\mathrm{K}$ " dan komponen lainnya yang terkait dengan rumus harga pembelian TBS. dalam menetapkan indeks "K" dan harga patokan TBS. Dalam menetapkan indeks " $\mathrm{K}$ " dan harga dilakukan sekurang-kurangnya dua minggu sekali. Di Provinsi Jambi Tim Penetapan Harga TBS pada awalnya bekerja setiap dua minggu. Sejak akhir tahun 2011 Tim ini bekerja menetapkan harga TBS setiap minggu dan indeks "K" setiap bulan.

Untuk periode waktu menetapkan harga TBS, Tim bekerja berdasarkan pada ketentuan pasal 5 Pemertan nomor 17 tahun 2010 yaitu harga TBS ditentukan berdasarkan rumus tertentu dimana terdapat besaran indeks $\mathrm{K}$ yang keberadaannya masih mengundang berbagai pertanyaan karena dianggap menjadi faktor penekan terhadap harga TBS yang akan diterima petani. Pada Lampiran Pemertan nomor 17 tahun 2010, dasar perhitungan indeks K diatur padar butir IX ayat 1. Diuraikan bahwa penetapan indeks "K" dilakukan berdasarkan harga penjualan, biaya pengolahan dan pemasaran minyak sawit kasar (CPO) dan inti Sawit (PK) serta biaya penyusutan. Selanjutnya dalam ayat (2) butir IX tentang rincian biaya pada ayat 1 , ternyata ada variabel tambahan selain komponen pada ayat 1 yaitu biaya operasional tidak langsung yang dimasukkan dalam perhitungan indeks K. Meskipun harga TBS sudah ditetapkan pemerintah, tetapi pada dasarnya setiap perusahaan PKS memiliki kebijakan sendiri dalam menetapkan harga beli TBSnya. Faktanya diantara PKS terdapat selisih harga yang ditetapkan dengan harga real pabrik. Perbedaan itu ada yang lebih rendah maupun lebih tinggi dari harga penetapan. Satu hal yang pasti adalah bahwa harga TBS real yang diterima petani sepenuhnya ditetapan oleh perusahaan PSK, petani hanya menerima harga ( price taker).

Sementara itu pola kemitraan yang dibangun antara perusahaan PKS sebagai inti dan petani kelapa sawit sebagai plasma di beberapa wilayah perkebunan kelapa sawit terutama ditunjukkan untuk melindungi petani dari kesenjangan harga. Dalam penelitian Asri Yasri (2006), mengatakan bahwa pendapatan kebun plasma dan kebun inti dengan pola PIR-BUN lebih tinggi dari pendapatan kebun plasma dengan pola kemitraan KKPA. Dampak pola kemitraan terhadap kesejahteraan petani setidaknya dapat dilihat dari kebijakan harga TBS tersebut, apakah PKS telah berpihak pada petani atau tidak. Semakin besar nilai indeks K maka akan semakin tinggi harga yang diterima petani, dengan asumsi faktor lainnya konstan. Selama posisi PKS lebih menentukan, apalagi nilai indeks $\mathrm{K}$ yang berpengaruh besar terhadap harga TBS lebih ditentukan oleh kebijakan dan pertimbangan bisnis PKS, maka selama itu pula perdebatan dalam penetapan harga khusunya mengenai komponen indek $\mathrm{K}$ akan tetap berlanjut dan berujung pada rasa ketidak-adilan disinilah letak persoalannya sehingga dianggap perlu suatu penelitian yang mempelajari tentang faktor penentu besaran indeks "K" dan kebijakan penetapan terutama harga TBS oleh PKS karena meskipun ada campur tangan pemerintah termasuk mengembangkan pola kemitraan, maka permasalahaanya adalah dimana pembeli dalam hal ini PKS memiliki posisi yang lebih dominan, sesungguhnya terjadi. Oleh karena itu 
kajian ini berusaha untuk mempelajari dan menganalisis pengaruh variabel biaya pengolahan dan pemasaran minyak sawit kasar (CPO) dan inti sawit (PK), biaya penyusutan dan biaya operasional tidak langsung dalam besaran indeks $\mathrm{K}$ yang ditetapkan ditingkat provinsi. Disamping itu juga mempelajari kebijakan harga beli TBS masing-masing perusahan PKS pada posisi diatas harga patokan dan dibawah harga patokan khususnya PKS yang memiliki kemitraan dengan Koperasi/petani.

\section{METODE PENELITIAN}

\section{Penentuan Lokasi dan Waktu Penelitian}

Penelitian dilaksanakan di sentra produksi kelapa sawit yang memiliki PKS dan bermitra dengan petani khususnya di Kabupaten Muaro Jambi. Di Provinsi Jambi terdapat lebih kurang 30-an PKS diantaranya yang bermitra dengan petani dengan pola PIR dan KKPA. Penelitian ini dilakukan pada 1 perusahaan PKS yang menetapkan harga beli TBS lebih rata-rata tinggi dari harga patokan provinsi dan 1 perusahaan yang menetapkan harga TBS lebih rendah dari harga patokan provinsi dan satu perusahaan yang menetapkan harga beli sama dengan keputusan Tim Penetapan harga TBS. semua responden terdiri dari unsur pinjaman PKS dan petani mitranya yang diakili oleh KUD.

\section{Sumber dan Pengumpulan Data}

Desain penelitian ini merupakan kajian data historis kasus pada PKS yang bermitra Investasi perkebunan kelapa sawit yang mengundang investor membangun pabrik pengolahan kelapa sawit mengharuskan adanya kerjasama perusahaan dengan masyarakat petani di daerah setempat karena setiap PKS wajib memiliki kebun sendiri minimal $20 \%$ dari kapsitas terpasangnya. Berbagai pola kerjasama tersebut tertuang dalam skim (pola) pembiayaan diantaranya melalui Perusahaan Inti Rakyat (PIR) atau PIR Transmigrasi dan Kredit Koperasi Primer pada Angggota (KKPA).

Perusahaan yang data invoice-nya (data penjualan) dijadikan sebagai sumber data penelitian adalah PTP Nusantara VI, yang mewakili pola kemitraan PIR Trans, PT. BGR yang mewakili kemitraan kombinasi PIR Trans dan KKPA, dan PT KS yang mewakili pola kemitraan KKPA (Kredit Primer Koperasi pada Anggota). Data dimbil bersumber dari dokumen invoice yang disampaikan oleh PKS ke dalam rapat penetapan harga TBS selama kurun waktu yang semula satu tahun, tetapi karena tidak semua perusahaan menyampaikan datanya secara lengkap pada tiap pertemuan/rapat penetapan harga, maka diputuskan untuk mengumpulkan data historis selama kurun waktu tiga tahun, yaitu tahun 2009,2010, dan 2011. Disamping itu dalam rangka membandingkan antara harga patokan provinsi dengan harga riil yang diterima petani anggota Kelompok Tani atau KUD, dilakukan survei terhadap lokasi PKS dengan melakukan interview terhadap pengurus KUD/Kelompok Tani mitra Perusahaan Pabrik Kelapa Sawit dengan melakukan interview kepada tokoh masyarakat atau pengurus KUD/Kelompok Tani/Gapoktan. Untuk pola Kemitraan PIR-Tran diambil responden tokoh masyarakat yang menjadi pengurus KUD Unit VI setempat. Di PT BGR, dilakukan interview terhadap pengurus Gabungan Kelompok Tani sedangkan di Lokasi PT KS dilakukan interview dengan pengurus KUD Akso Dano Sekernan. 
Untuk mendapatkan data dan informasi objektif sesuai dengan kebutuhan penelitian, maka dilakukan pengumpulan data dan informasi dengan menggunakan berbagai teknik sebagai berikut:

1. Wawancara (interview), dilakukan untuk mengumpulkan data dan informasi kuantitatif dan kualitatif dari kelompok sasaran (pabrikan dan petani) yang telah ditetapkan. Data dan informasi yang dikumpulkan melalui pendekatan ini berkenaan dengan kebijakan penetapan harga TBS.

2. Wawancara mendalam (in depth interview), dimaksudkan untuk mengetahui aspekaspek kualitatif secara lebih mendalam dan komprehensif. Pelaksanaan wawancara tidak hanya sekali atau dua kali melainkan berulang-ulang dengan intensitas yang tinggi. Untuk itu sasaran wawancara mendalam (in-depth interview) ini adalah informan kunci key informan yang memiliki kompetensi dengan kajian yang ditelaah.

3. Observasi langsung ke lapangan (direct observation) dimaksudkan untuk mengetahui dan melihat secara langsung bagaimana penetapan harga TBS dan senjang harga yang terjadi di tingkat petani sebagai Mitra perusahaan.

\section{Metode analisis}

Analisis kuantitatif dilakukan untuk menjawab dan mempertajam tujuan satu dengan menggunakan regresi linear berganda (Sugiyono, 2006) sebagai berikut

$\mathrm{IK}_{\mathrm{i}}=\mathrm{f}(\mathrm{BOi}, \mathrm{Bpi}, \mathrm{BDi}, \mathrm{BTLi})$

Dengan persamaan

$\mathrm{IK}_{\mathrm{i}}=\mathrm{a}+\beta_{1} \mathrm{BO}+\beta_{2} \mathrm{Bpi}+\beta_{3} \mathrm{BDi}+\beta_{4} \mathrm{BTLi}+\mathrm{e}$

$\mathrm{IK}=$ Indeks $\mathrm{K}$

$\mathrm{BO}=$ Biaya pengolahan

$\mathrm{BP}=$ Biaya Pemasaran

$\mathrm{BD}=$ Biaya Penyusutan

$\mathrm{BTL}=$ biaya Tidak Langsung

$\mathrm{I}=$ periode penetapan harga sampai $\mathrm{n}$ periode tergantung pada ketersediaan data

e adalah disturbance term

sedangkan $\beta_{1} \beta_{2} \beta_{3}$ dan $\beta_{4}$ masing-masing adalah parameter yang akan dicari dan diamati pengaruhnya terhadap perubahan besaran nilai indeks " $\mathrm{K}$ " tingkat provinsi.

\section{Pengujian hipotesis}

Pengujian secara parsial (Uji t-stat)

Uji $t$ adalah uji yang biasa digunakan oleh para ahli ekonometrika untuk menguji hipotesis tentang koefisien-koefisien korelasi secara Individual. Pertama-tama setelah data diproses akan dilakukan uji signifikansi individu melalui uji t ini. Uji t-stat ini menguji apakah masing-masing variabel independen dalam model yang di korelasi mempengaruhi variabel dependen secara signifikan adalah sebagai berikut :

$\mathrm{H}_{0}=\beta=0$ artinya variabel independen tersebut tidak signifikan mempengaruhi

$\mathrm{H}_{1}=\beta \neq 0$ artinya variabel independen tersebut signifikan mempengaruhi

Sedangkan tingkat kriteria penolakan adalah : tolak $\mathrm{H}_{0}$ bila probabilitas t-stat $<0.10$

Tingkat kepercayaan pada $90 \%$ di mana $\alpha=10 \%$ 


\section{Pengujian serentak (Uji F-Stat)}

Selain dilakukan pengujian nya secara individu pengujian serentak juga dilakukan yaitu melalui uji F-Stat. Hipotesa dan kriteria penolakan nya adalah sebagai berikut :

Hipotesa untuk Uji F-Stat:

$\mathrm{H}_{0}: \beta:{ }_{1}=\beta_{2}=\ldots=\beta_{k}=0$ Artinya variabel variabel independen yang terdapat pada model secara tidak signifikan mempengaruhi

$\mathrm{H}_{0}: \beta:_{1} \neq \beta_{2}=\neq \ldots \neq \beta_{k} \neq 0$ Artinya variabel variabel independen yang terdapat pada model secara signifikan mempengaruhi

Kriteria penolakan : Tolak $\mathrm{H}_{0}$ bila probabilitas F-Stat $<0.10$ tingkat kepercayaan $80 \%$ di mana $\alpha=10 \%$

\section{Uji R-Squared}

Uji R-Squared atau $\mathrm{R}^{2}$ merupakan uji kecocokan model regresi yang menggambarkan kemampuan model dalam menjelaskan perubahan pada variabel dependen. 


\section{HASIL PENELITIAN}

\section{Perkembangan harga ekspor CPO}

Data keadaan harga ekspor CPO di tingkat eksportir (harga FOB) selama 3 tahun 2009-2011 tertera pada tabel 1. Jika data di pilah menurut kenaikan atau penurunan dalam periode tertentu maka dapat dilihat bahwa trend perkembangan harga ekspor selama 3 tahun bahwa pada bulan-bulan awal hingga pertengahan tahun terjadi peningkatan harga, tetapi pada periode akhir tahun turun menjadi fluktuatif yang mula-mula naik kemudian menurun secara keseluruhan kecenderungan harga meningkat dengan kenaikan rata-rata 1.02 persen per tahun dari Rp 5,096.11/kg Pada Januari 2009 menjadi Rp 7,132.95/kg pada bulan desember 2011. Berbeda dengan tahun-tahun sebelumnya yang cenderung meningkat yaitu pada tahun 2009 naik 2,09 persen per bulan dan tahun 2010 naik ratarata lebih tinggi yaitu 2,3 persen per bulan, pada tahun 2011 cenderung menurun dengan laju penurunan sebesar -1,41 persen per bulan.

Tabel 1. Perkembangan Harga CPO berdasarkan penjualan perusahaan pada tingkat FOB $(\mathrm{Rp} / \mathrm{kg})$ di Provinsi Jambi

\begin{tabular}{lccc}
\hline Bulan & $\mathbf{2 0 0 9}$ & $\mathbf{2 0 1 0}$ & $\mathbf{2 0 1 1}$ \\
\hline Januari & $5.096,11$ & $6.452,26$ & $8.588,30$ \\
Februari & $5.767,27$ & $6.458,08$ & $8.419,46$ \\
Maret & $6.789,98$ & $6.789,98$ & $7.494,57$ \\
April & $6.534,37$ & $6.527,62$ & $7.428,09$ \\
Mei & $7.639,58$ & $6.628,93$ & $7.771,83$ \\
Juni & $6.930,83$ & $6.505,94$ & $7.703,94$ \\
Juli & $5.872,32$ & $6.314,10$ & $6.690,34$ \\
Agustus & $6.164,81$ & $6.941,81$ & $6.690,34$ \\
September & $6.354,10$ & $7.137,31$ & $7.430,66$ \\
Oktober & $5.739,50$ & $7.250,52$ & $6.644,00$ \\
November & $5.847,89$ & $7.972,94$ & $5.174,76$ \\
Desember & $6.373,09$ & $8.300,63$ & $7.132,95$ \\
\hline Sumb: Dina & Perke &
\end{tabular}

Sumber: Dinas Perkebunan Provinsi Jambi 2012. Data Diolah

\section{Perkembangan harga ekspor inti}

Sejalan dengan perkembangan harga CPO maka kenaikan harga minyak inti sawit di tingkat ekspor juga terjadi pada periode awal tahun, tetapi harga berfluktuasi lebih cepat dibandingkan dengan harga CPO. Kecenderungan perubahan pada periode yang sama selama 3 tahun pada periode awal tahun hingga pertengahan dan selanjutnya menurun di akhir tahun. Laju peningkatan tahunan menunjukkan bahwa terjadi peningkatan harga dari tahun 2009 hingga tahun 2010 tetapi pada tahun 2011 harga bergerak turun dengan pasti pada laju penurunan 3 persen \% tiap bulan. Pada bulan Januari 2009 R p2045.57/kg meningkat menjadi Rp 2,678.28/kg pada bulan Desember. Pada periode yang sama pada tahun 2010 harga meningkat dengan lebih tajam yaitu dari Rp. $2,971.67 / \mathrm{kg}$ menjadi $5750.19 / \mathrm{kg}$, naik rata-rata 7,8 persen per bulan. Secara rinci kondisi ini dapat dilihat pada tabel 2 berikut. 
Tabel 2. Perkembangan harga Inti Sawit (Palm Kernel Oil) tahun 2009-2011 (Rp/Kg) berdasarkan penjualan perusahaan pada tingkat FOB

\begin{tabular}{lrrr}
\hline Bulan & $\mathbf{2 0 0 9}$ & $\mathbf{2 0 1 0}$ & $\mathbf{2 0 1 1}$ \\
\hline Januari & 2045,57 & 2971,67 & 6599,43 \\
Februari & 2204,98 & 3202,38 & 7205,3 \\
Maret & 2570,89 & 3626,92 & 6376,33 \\
April & 3262,24 & 3644,87 & 6337,93 \\
Mei & 3235,06 & 3739,78 & 6994,78 \\
Juni & 2526,78 & 3831,42 & 6026,09 \\
Juli & 2631,98 & 3815,24 & 3392,42 \\
Agustus & 2631,98 & 4135,05 & 3250,68 \\
September & 2649,12 & 4339,93 & 3507,99 \\
Oktober & 2481,07 & 4807,82 & 2551,79 \\
November & 2521,9 & 5373,08 & 2424,65 \\
Desember & 2678,28 & 5750,19 & 3876,52 \\
\hline Sumbr:
\end{tabular}

Sumber: Dinas Perkebunan Provinsi Jambi, 2012. Data diolah

Kecenderungan merosotnya harga $\mathrm{CPO}$ dan minyak inti sawit yang berlangsung hingga akhir tahun 2012disebabkan oleh beberapa faktor yaitu:

1. Masih belum tuntasnya krisis ekonomi Eropa yang dipicu oleh membengkaknya hutang Yunani dan Italia yang mengganggu keseimbangan industri eropa secara keseluruhan

2. Melemahnya permintaan $\mathrm{CPO}$ dari 2 negara industri berkembang yang baru yaitu India dan Cina

3. Berkembangnya isu lingkungan hidup di mana kelapa sawit dianggap sebagai usaha budidaya yang merusak paru-paru dunia

4. Belum dapat dipenuhi nya sebagian besar persyaratan SP yang ditetapkan oleh negara-negara importir sehingga menurunkan permintaan negara-negara potensial di Eropa

\section{Perkembangan Indeks $\mathrm{K}$}

Perkembangan nilai indeks K selama periode 2009 sampai 2011 diterapkan pada tabel 3. Dapat dilihat bahwa nilai indeks K selama periode waktu tersebut menunjukkan perubahan yang tidak benar. Pada awal tahun 2009 nilai indeks $\mathrm{K}$ sebesar 84.33 persen dan di akhir tahun menjadi 86.87 persen atau naik sebesar 2.54 persen. Begitu pula pada tahun 2010 nilai indeks masih cenderung naik tetapi pada tahun 2011 ada penurunan sebesar 1,26 persen di akhir tahun yaitu dari 88.6 persen pada bulan Januari selama menjadi 87.34 persen pada bulan desember 2011.

Tabel 3. Keadaan nilai Indeks K pada tahun 2009 sampai 2011

\begin{tabular}{lccc}
\hline \multirow{2}{*}{ Bulan } & \multicolumn{3}{c}{ Tahun } \\
\cline { 2 - 4 } & $\mathbf{2 0 0 9}$ & $\mathbf{2 0 1 0}$ & $\mathbf{2 0 1 1}$ \\
\hline Januari & 84,33 & 86,91 & 88,60 \\
Februari & 85,66 & 87,00 & 88,73 \\
Maret & 86,29 & 86,00 & 88,17 \\
\hline
\end{tabular}




\begin{tabular}{llll}
\hline April & 87,40 & 86,00 & 87,53 \\
Mei & 87,80 & 86,30 & 87,35 \\
Juni & 87,42 & 86,92 & 87,84 \\
Juli & 86,18 & 86,03 & 88,45 \\
Agustus & 86,63 & 86,91 & 88,76 \\
September & 87,24 & 87,43 & 88,12 \\
Oktober & 86,82 & 87,70 & 87,39 \\
November & 86,71 & 88,17 & 87,35 \\
Desember & 86,87 & 88,52 & 87,34 \\
\hline
\end{tabular}

Sumber: Dinas Perkebunan Provinsi Jambi, 2012. Data diolah

\section{Faktor-faktor yang mempengaruhi nilai indeks $\mathrm{K}$}

Untuk menganalisis pengaruh faktor biaya pengolahan (BO), biaya pemasaran (BP), biaya penyusutan (BD) dan biaya administrasi ADM di pergunakan data yang berasal dari tabel perhitungan indeks $\mathrm{K}$ dari perusahaan yang mengikuti rapat penetapan harga TBS Dinas Provinsi Jambi. Kendala yang dihadapi dalam penelitian ini adalah tidak semua PKS yang hadir menyampaikan data yang diperlukan karena berbagai alasan misalnya karena sedang tidak ada kontrak atau kontrak yang lalu belum bisa dipenuh, sehingga pada kesempatan tersebut tidak memberikan data invoice atau perhitungan indeks K. Akibatnya perhitungan indeks K yang berasal dari data ketiga perusahaan yang menjadi sampel penelitian ini tidak berhasil dihimpun. Dengan asumsi bahwa keputusan penetapan harga yang dilakukan oleh tim penetapan harga TBS berlaku untuk semua perusahaan PKS yang ada di provinsi Jambi maka data yang diambil untuk menghimpun dan menghitung biaya biaya tersebut di atas diambil dari peluruhan data yang masuk dalam perhitungan indeks K. Pada tahun 2009 dan 2010 data yang dimaksud tidak tersedia, yang tersedia adalah data indeks K dari tahun 2011 sampai 2012 sehingga data yang berhasil dikumpulkan dan direkap seperti tertera pada tabel 4 .

Tabel 4. Keadaan Indeks K, Biaya Pemasaran, biaya penolahan, Biaya Penyusutan dan Biaya tidak Langsung

\begin{tabular}{llllll}
\hline $\begin{array}{l}\text { No. } \\
\text { Perusahaan }\end{array}$ & Indeks K & $\begin{array}{l}\text { Biaya } \\
\text { Pemasaran }\end{array}$ & $\begin{array}{l}\text { biaya } \\
\text { penolahan }\end{array}$ & $\begin{array}{l}\text { Biaya } \\
\text { Penyusutan }\end{array}$ & $\begin{array}{l}\text { Biaya tidak } \\
\text { Langsung }\end{array}$ \\
\hline 1 & 86,56 & 86,53 & 109,42 & 37,53 & 71,89 \\
2 & 88,67 & 90 & 105,51 & 25 & 80,51 \\
3 & 84,47 & 130,81 & 112,16 & 42,6 & 69,56 \\
4 & 86,95 & 112,23 & 99,49 & 15,41 & 84,08 \\
5 & 87,82 & 86,53 & 123,25 & 37,53 & 85,72 \\
6 & 88,35 & 107,23 & 102,78 & 18,97 & 83,81 \\
7 & 87,68 & 91,97 & 94,24 & 19,06 & 75,18 \\
8 & 82,74 & 106,62 & 100,89 & 32,13 & 68,76 \\
9 & 86,37 & 140 & 99,56 & 26,44 & 73,12 \\
10 & 86,65 & 96,65 & 87,9 & 20,7 & 67,2 \\
11 & 88,21 & 108,89 & 110,15 & 36,95 & 73,2 \\
12 & 87,48 & 90,61 & 113,11 & 32,28 & 80,83 \\
13 & 88,21 & 90 & 104,46 & 12,1 & 92,36 \\
14 & 87,15 & 86,53 & 119,19 & 37,5 & 81,69 \\
15 & 88,34 & 86,53 & 11,7 & 37,5 & 73,2 \\
\hline
\end{tabular}


Hasil uji statistik terhadap data tabel 4 tercantum pada tabel 5. Dalam proses pengolahan data terjadi perbedaan dalam hasil yang ditampilkan karena variabel biaya penyusutan (BD) tidak masuk dalam model, karena data tersebut tereliminasi karena nilai variabel beda dianggap mengganggu ketetapan model (Goodness of Fit). Meskipun demikian nilai $\mathrm{R}^{2}$ masih rendah yaitu sebesar 41.9 persen artinya hanya 41.9 persen besaran indeks dapat ditentukan oleh variabel biaya pengolahan, biaya pemasaran, biaya penyusutan dan biaya tidak langsung, selebihnya sebesar 58,1 persen ditentukan oleh variabel lain di luar model yang dipakai.

Tabel 5. Pengaruh biaya pengolahan, biaya pemasaran, biaya penyusutan dan biaya administrasi terhadap nilai indeks $\mathrm{K}$

\begin{tabular}{llllll}
\hline $\begin{array}{l}\text { Unstandardized } \\
\text { Coefficients }\end{array}$ & \multicolumn{2}{l}{ Standardized Coefficients } & $\mathrm{t}$ & sig. \\
\hline Konstanta) & 83.562 & 6.628 & & 12.607 & .000 \\
Biaya Olah (BO) & -.031 & .024 & -.323 & -1.302 & .220 \\
Biaya Pemasaran (BP) & -.017 & .043 & -.101 & -.408 & .691 \\
Biaya Administrasi (ADM) & .109 & .056 & .497 & 1.963 & .075 \\
\hline
\end{tabular}

Pada tabel 5 dapat dilihat bahwa secara parsial hanya variabel biaya administrasi (ADM) yang berpengaruh nyata terhadap besaran nilai indeks $\mathrm{K}$, sedangkan variabel biaya pengolahan dan biaya pemasaran berpengaruh tetapi tidak nyata. Namun secara bersama-sama ketiga variabel tersebut nyata pada tingkat 90 persen (tingkat signifikansi 10 persen).

\section{4 kebijakan penetapan harga TBS}

Harga yang diterima petani adalah hal yang sangat penting dalam konteks menyejahterakan kehidupan rakyat, karena paling dirasakan langsung pada kemampuan daya beli. Tabel 6 menunjukkan perbedaan antara ketetapan tim penetapan harga TBS dengan harga beli pabrik di pabrik yang dibeli dari petani melalui KUD atau kelompok tani di ketiga lokasi PKS.

Tabel 6 senjang harga TBS petani di tingkat pabrik dan harga ketetapan tim provinsi berdasarkan pola kemitraan

\begin{tabular}{lcccc}
\hline Bulan & $\begin{array}{l}\text { Harga } \\
\text { Ketetapan Tim }\end{array}$ & $\begin{array}{l}\text { Harga Beli Pola } \\
\text { PIRTran+KKPA }\end{array}$ & $\begin{array}{l}\text { Harga beli Pola } \\
\text { PIR Tran }\end{array}$ & $\begin{array}{l}\text { Harga beli Pola } \\
\text { KKPA }\end{array}$ \\
\hline Februari 2011 & $1.405,52$ & $1.475,796$ & $1.305,52$ & $1.405,52$ \\
Maret 2011 & $1.569,72$ & $1.648,206$ & $1.469,72$ & $1.569,72$ \\
April 2011 & $1.399,70$ & $1.469,685$ & $1.299,70$ & $1.399,70$ \\
Mei 2011 & $1.549,34$ & $1.626,807$ & $1.449,34$ & $1.549,34$ \\
Juni 2011 & $1.578,83$ & $1.657,772$ & $1.478,83$ & $1.578,83$ \\
Juli 2011 & $1.546,91$ & $1.624,256$ & $1.446,91$ & $1.546,91$ \\
Agustus 2011 & $1.579,43$ & $1.658,402$ & $1.479,43$ & $1.579,43$ \\
September & $1.472,15$ & $1.545,758$ & $1.371,15$ & $1.472,15$ \\
2011 & $1.424,63$ & $1.495,862$ & $1.324,63$ & $1.424,63$ \\
Oktober 2011 & $1.563,45$ & $1.641,623$ & $1.463,45$ & $1.563,45$ \\
November & & & & \\
2011 & & & & \\
\hline
\end{tabular}




\begin{tabular}{lllll}
\hline Desember 2011 & $1.553,63$ & $1.631,312$ & $1.453,63$ & $1.553,63$ \\
Januari 2012 & $1.637,65$ & $1.719,533$ & $1.537,65$ & $1.637,65$ \\
Februari 2012 & $1.667,45$ & $1.750,823$ & $1.567,45$ & $1.667,45$ \\
Maret 2012 & $1.694,78$ & $1.779,519$ & $1.594,78$ & $1.694,78$ \\
April 2012 & $1.903,20$ & $1.998,360$ & $1.803,20$ & $1.903,20$ \\
Mei 2012 & $1.771,41$ & $1.859,981$ & $1.671,41$ & $1.771,41$ \\
Juni 2012 & $1.511,73$ & $1.587,317$ & $1.411,73$ & $1.511,73$ \\
Juli 2012 & $1.609,47$ & $1.689,955$ & $1.509,47$ & $1.609,47$ \\
Agustus 2012 & $1.567,37$ & $1.645,739$ & $1.467,37$ & $1.567,37$ \\
\hline
\end{tabular}

Dari tabel 6 dapat dilihat bahwa harga yang ditetapkan oleh ketiga perusahaan dalam penelitian ini memiliki kebijakan yang berbeda. Perusahaan BGR dengan pola kemitraan PIR-Tran+KKPA yang yang investornya berasal dari Malaysia justru menetapkan harga yang lebih tinggi dari harga beli ketetapan tim provinsi, sedangkan yang paling rendah menetapkan harga beli TBS petani dari ketiga perusahaan tersebut adalah PTP Nusantara VI yang menerapkan pola PIR-Trans, sedangkan PT KS yang menerapkan pola KKPA cenderung memilih posisi kebijakan yang lebih aman Yaitu mengikuti ketentuan yang dilakukan oleh tim penetapan harga TBS provinsi.

\section{PEMBAHASAN}

\section{Faktor penentu besaran index $\mathrm{K}$}

Dari hasil analisis data telah diketahui bahwa hanya faktor biaya tidak langsung yang berpengaruh nyata pada besar atau kecilnya nilai indeks $\mathrm{K}$, sedangkan faktor biaya pengolahan dan biaya pemasaran berpengaruh tidak nyata terhadap besar atau kecilnya nilai indeks K. Sementara itu biaya penyusutan yang faktanya mempunyai andil dalam menentukan nilai indeks $\mathrm{K}$ tidak tepat dimasukkan dalam model analisis karena akan memperkecil nilai $\mathrm{R}^{2}$. Dalam pengamatan empiris sebenarnya variabel penyusutan ini juga masuk dalam perdebatan sengit antara petani dan dalam pengamatan empiris sebenarnya variabel penyusutan ini juga masuk dalam perdebatan sengit antara petani dan PKS.

Meskipun biaya tidak langsung berpengaruh nyata terhadap perubahan indeks $\mathrm{K}$, tetapi arah perubahannya tidak seperti yang diinginkan karena bernilai positif, yang berarti untuk menaikkan nilai indeks perlu dinaikkan pula biaya tidak langsung yang selama pengamatan justru bertentangan dengan keinginan petani. Oleh karena itu perbaikan model analisis pada penelitian berikutnya adalah kemungkinan memasukkan variabel lain dalam model analisis sehingga kajian yang lebih luas dan mendalam sangat direkomendasikan bagi penelitian berikutnya.

\section{Kebijakan harga: pendekatan teori monopoli bilateral dan kemitraan}

Sehubungan dengan penetapan harga input kelapa sawit (TBS) maka perusahaan Oligopoli di pasar CPO dan oligopsoni di pasar TBS, dipastikan akan menaikkan atau menurunkan harga dengan menjaga kondisi keuntungan maksimum atau biaya minimum operasi pabriknya. Dengan bergabungnya perusahaan PKS dalam GAPKI (gabungan pengusaha kelapa sawit) dan Petani dalam gabungan kelompok tani (GAPOKTAN) atau dan KUD yang melakukan tawar-menawar dalam penetapan harga karena dalam pasar 
oligopsonistik di pasar TBS berubah menjadi pihak GAPKI satu-satunya wakil pembeli berhadapan dengan GAPOKTAN atau KUD satu-satunya wakil penjual TBS.

Dari sudut pandang pasar, dimana proses supply-demand TBS dalam penetapan harga dilakukan secara bilateral antara Petani dalam KUD atau GAPOKTAN dengan PKS dalam GAPKI, maka model pasar terpenting ini disebut pasar monopoli bilateral (koutsoyiannis, 1982). Bagaimanapun kepentingan antara monopolis dan monopsonis akan tetap berjarak seperti terjadi kesepakatan yang dilakukan dalam konteks monopolis bilateral tersebut ditengahi oleh Peraturan Menteri Pertanian nomor 17 tahun 2010. Gabungan perusahaan dianggap sebagai monopsoni sementara gabungan petani dianggap sebagai monopolis.

Meskipun demikian dalam mempertahankan eksistensinya sebagai sebuah perusahaan yang berorientasi bisnis, maka faktor mencapai keuntungan maksimum tetap menjadi pijakan utama (Pindyck dan Rubinfeld, 1989). Dalam hal ini Keseimbangan produsen Secara teoritis akan dicapai jika biaya Marginal (BM) sama dengan penerimaan marginal (PM). Jika berada pada pasar persaingan oligopsonistik dan Keseimbangan produsen tidak tercapai maka perusahaan dengan mudah dapat melakukan tindakan efisiensi dengan salah satu cara yaitu menurunkan harga beli TBS. Dari formula penetapan harga TBS menurut pemeran 17 tahun 2010 tersebut diketahui bahwa variabel penentunya adalah nilai indeks $\mathrm{K}$, harga FOB CPO dan inti, serta rendemen CPO dan inti sawit. IndeksK merupakan besaran koefisien yang dapat dibentuk di tetapkan oleh perusahaan berdasarkan prinsip keuntungan maksimum nya.

Meskipun tidak selalu positif dampaknya, adanya faktor kemitraan dan peraturan menteri tentang penetapan harga menyebabkan perusahaan PKS menjadi terbatas kebebasannya dalam menetapkan harga beli TBS karena masuk dalam struktur pasar monopoli bilateral.

\section{KESIMPULAN}

Dari hasil penelitian ini dapat disimpulkan beberapa temuan sebagai berikut:

1. Satu faktor yang menentukan dalam menghitung besaran nilai indeks $\mathrm{K}$ adalah biaya pengolahan, biaya pemasaran, dan biaya tidak langsung.

2. Kebijakan penetapan harga berhasil mengendalikan disparitas harga beli TBS antara perusahaan dengan pola pembiayaan PIR-Trans,PIR plus KKPA serta pola KKPA. Harga beli TBS tertinggi ditetapkan oleh Manajemen Perusahaan PKS dengan pola PIR Trans plus KKPA yang dikelola oleh perusahaan asing yaitu diatas harga ketetapan tim, sementara kebijakan perusahaan dengan pola PIR Trans menetapkan harga beli TBS lebih rendah dari harga TBS yang ditetapkan tim perusahaan yang memenuhi ketetapan harga tim adalah perusahaan KS yang membangun perusahaan perkebunan kelapa sawit dengan pola KKPA. 


\section{UCAPAN TERIMA KASIH}

Penulis menyadari bahwa sungguh banyak keterbatasan yang dimiliki dalam mengembangkan kepercayaan untuk melakukan penelitian yang diberikan dan didanai oleh program magister agribisnis pascasarjana universitas Jambi ini. Untuk itu secara khusus penulis mengucapkan terima kasih yang tak terhingga kepada ketua program magister agribisnis pascasarjana universitas Jambi. Terima kasih juga disampaikan kepada para kolega yang telah banyak membantu terlaksananya penelitian ini

\section{DAFTAR PUSTAKA}

Asri Yasri. 2006. Analisis Pendapatan dan Penyerapan Tenaga Kerja pada Sistem Kemitraan Usaha Perkebunan kelapa sawit. Institut Pertanian Bogor. Bogor

Dinas Perkebunan Provinsi Jambi. 2011. perkebunan dalam angka

Koutsoyiannis, A. 1982. Modern Micro Economics. second edition the Macmillian Press Ltd.Printed in Hongkong.

Pindyck, Robert.S. dan Daniel L. Rubinfield. 1989. Microeconomics. Macmillian Publishing Company. New York

Sugiyono, 2006. Metode Penelitian bisnis. CV Alfabeta. Jakarta 
Journsl of Agribusiness and Local Wisdom

eISSN: 2621-1300 (e); 2621-1297 (p), Volume 1. no (1) 2018 